\title{
Gender and musical performance in Maracatus (PE) and Bumba Bois (MA)'
}

\author{
Lady Selma Ferreira Albernaz \\ Anthropology Graduate Program - UFPE
}

\section{Beginnings $^{2}$}

As one observes Maracatu and Bumba Meu Boi, one's attention is drawn to the arrangements of gender relations and how they shape men's and women's positions in each group. Musical performances do not escape this rule, women prevailing among the players of certain instruments, being singers and song composers in specific occasions, with apparently well-defined and ranked spaces and powers. Bodily expressions denote a classificatory order of gender, not necessarily corresponding to biological sex, reinforcing the meanings of the positions occupied by men and women. A set of relations is prescribed for male and female members to the disadvantage of the latter, and in some cases new positions for women are matters of heated debate.

1 My sincerely acknowledges to Homero Ferreira Lima for the translated, to Peter Fry and Luciana Mendonça for the revision and Parry Scott for the final revision.

2 This articles is part of results from the investigation: Concepções sobre corporeidade e fertilidade femininas entre brincantes de bumba meu boi maranhense e de maracatu pernambucano (CNPq - Process no 402901/2008-8; Edital no 57/2008). The research team comprised the following scientific initiation scholarship students: Teresa Maria Barbosa de Oliveira and Maíra Souza e Silva Acioli (2006/7), Bárbara Lopes Lima (2007/8), Patrícia Geórgia Barreto de Lima (2008/10), Ighara de Oliveira Neves (2009/10), all Social Science undergraduate students at Pernambuco Federal University (UFPE). Also part of the team was, Jailma Maria Oliveira (2009/10), Master's student at PPGA-UFPE. From April 2010 onwards I had the collaboration of Professor Jorge Freitas Branco (ISCTE/IUL) in this research, which lead to the development of my current post-doctorate project. For all those who cooperated I am very grateful. 
In Maracatu, women are especially noticed for playing abể. Less often they appear playing larger percussion instruments, such as large drums called alfaias, quite a surprising view in face of the strength necessary to carry and play these instruments. In singing, they draw attention in the choral chanting of the songs of praise (loas), orchestrated by the master of Maracatu during the parades and in rehearsals prior to presentations.

As for Bumba Meu Boi, the musical spotlight falls upon the amos (or masters). Their reputation will depend on their voice, intonation and melodies (toadas). The toadas start in the chapel, after which instruments are heard. Everyone joins the choir, indistinctively. The main percussion instruments are played by men, while women are in charge of smaller instruments such as the rattles and the wooden noisemaker ${ }^{4}$, which are secondary accompaniments to the central instruments. These instruments appear to be an extension of the performers' bodies as they give cadence and rhythm to the choreographies, which give the style to the dances.

In this article I try to unravel how musical performances are oriented by gender relations and meanings, while they relate to the musical value and symbolism within each of these playful dances.

I was an observer of Bumba Bois in Maranhão in 2001/2; 2007; 2009, always in the months of June and July, in the city of São Luis. This period is the apex of the cycle of festivities that begins after Lent and goes on, in general, until November. Rehearsals start at Easter, ending on Saint John's day (a date chosen by nearly all groups for the baptism of the animal representing the group). This day marks the cycle of presentations by the groups throughout the arraiais ${ }^{5}$ scattered across the city - delimitating the período junino (or the period related to the month of June), which in fact spills into late July. The cycle ends with the ritual of the bull's killing, which takes place from late July to November. ${ }^{6}$

3 For this word there are many spellings. I have chosen this one for being the closest to its pronunciation. It is a gourd covered with beads.

4 Bumba Bois's matracas (or noisemakers) are two small rectangular wooden planks (approximately $20 \mathrm{~cm} \mathrm{X} 7 \mathrm{~cm}$ ). One hits against the other accompanying the rhythm of the music.

5 Place where the São João parties occur, with stands and bars where food and drinks are sold and where there is a stage for various presentations. They are scattered virtually across every districts of the city.

6 This description is schematic. The groups create arrangements of their own to suit the demands of the state's cultural policies, as well as the demands of the cultural market (Albernaz 2004). 
Maracatu's activities begin with rehearsals, that usually start in September, ending during carnival. In this period, two relevant events occur: 1- the parades of Maracatu associations sponsored by the Municipality of Recife, when a champion is elected; 2- the Night of Silent Drums (Noite dos Tambores Silenciosos), in which tribute is paid to black ancestors (eguns)7. Throughout the year, the largest and most famous groups are invited to take part in parties and/or to offer workshops on percussion and on the history of Maracatu, with special emphasis on its religious aspects. Such invitations mean that some groups give workshops throughout Brazil and abroad, especially in European Countries (mainly, France and Germany). I started my investigation on Maracatus in 2009, initiating systematic fieldwork in November, which allowed me to witness rehearsals at Maracatus' headquarters, and rehearsals prior to carnival presentations ${ }^{8}$.

The text is in two parts. In the first part, I present a succinct description of Maracatu and Bumba Meu Boi, placing both in the contexts of the cities where they take place and how their identities depend on the music they play. In the second part, I focus upon the description of musical instruments and singing. I then examine gender relations, focusing upon classifications which shape musical practices, and relate to differentiated hierarchies and powers for men and women, with some disadvantages for the latter.

\section{Maracatus and Bumba Meu Bois - musicality and the assertion of regional identities.}

The maracatus are processions with dance and music, considered to be characteristic of the State of Pernambuco ${ }^{9}$, where there are in fact two kinds of Maracatus, Maracatu Nação or Baque Virado and Maracatu Rural or Baque

\footnotetext{
7 The Night of the Silent Drums has taken place in Recife since the 1960`s. Currently, it is sponsored by Recife's Municipality and attracts a large crowd.

8 The prévias de carnaval (rehearsals) begin in January and consist of balls in clubs or street processions promoted by carnival associations. Maracatu's rehearsals occur in the association's headquarters or in its vicinities, without attracting a large public. In the District of Recife (Bairro do Recife - the center of the city's carnival party) Maracatu's rehearsals are well-attended. I will go over details of the official opening later.

9 In the state of Ceará, Maracatu can also be found, allegedly taken there from Pernambuco. For people in Ceará, it was the other way around (Cruz 2008).
} 
Solto or Orquestra. The distinction is based on the rhythm, the instruments, the costumes, and the rural or urban origin. In this analysis I focus exclusively on Maracatu Nação ${ }^{10}$, which emphasizes and is recognized as having strong attachments to Afro-Brazilian religions. Some hold that its religious purpose is to worship black ancestors (eguns), while others contend that it aims at worshipping the divinities of Yoruba origin, the Orishas ${ }^{11}$.

Maracatu groups, in general, are comprised of an entourage and a set of batuqueiros (percussionists). The court is structured around a queen and a king. The royal couple are protected by a large umbrella and flanked by Roman soldiers and pages carrying fans - all of them are either young men or children. Completing the royal guard are spearholders who encircle the entourage as they parade.

The second most important character in the court's hierarchy is the Dama do Paço, often represented by two women, each carrying a calunga (kind of doll), which incarnates religious deities and contains the spiritual foundations which protect the group. Next in the hierarchy, is a group of noble couples, following the entourage, made up of a Prince and a Princess, and also a Count, a Duke, a Marquis. Other noble titles are possible, and vary in number from one group to another - the larger the group, the larger the number of titles and couples. In some cases, the adult noble couples are duplicated by couples of children.

The Court is also made up of a group of Baianas ${ }^{12}$ (rich or poor - the latter can also be called catirinas), without a male pair. In the majority of the groups, male participants are allowed to appear in female dress. In some Maracatus, part of the rich Baianas represent orixás figures - deities of African-Brazilian cults. Men dressed as Baianas are much admired for their performance and elaborate costumes. There is also a caboclo (a masculine character dressed in feather costumes resembling an Indian) who goes around amidst the other characters with a distinctive dance made up of acrobatic leaps and crouchings.

10 In order to facilitate reading I will just use the term Maracatu to refer to Maracatu Nação.

11 This religious affiliation is the source of many different debates and would require a longer and more careful interpretation, which escapes the scope of this article. I will make reference, whenever necessary, to the religious reasons invoked to justify women's presence in musical performance.

12 Baianas appear in many Brazilian dances and festivities. They dress in the traditional clothes associated with women from Bahia, that is long skirts over multiple petticoats. 
The sequence of the procession is as follows: first, the Baianas and among them the Damas do Paço who protect the whole entourage. Next, the rich Baianas, the noble couples, and at the rear, the Royal Couple.

The picture below synthesizes a Maracatu's Court.

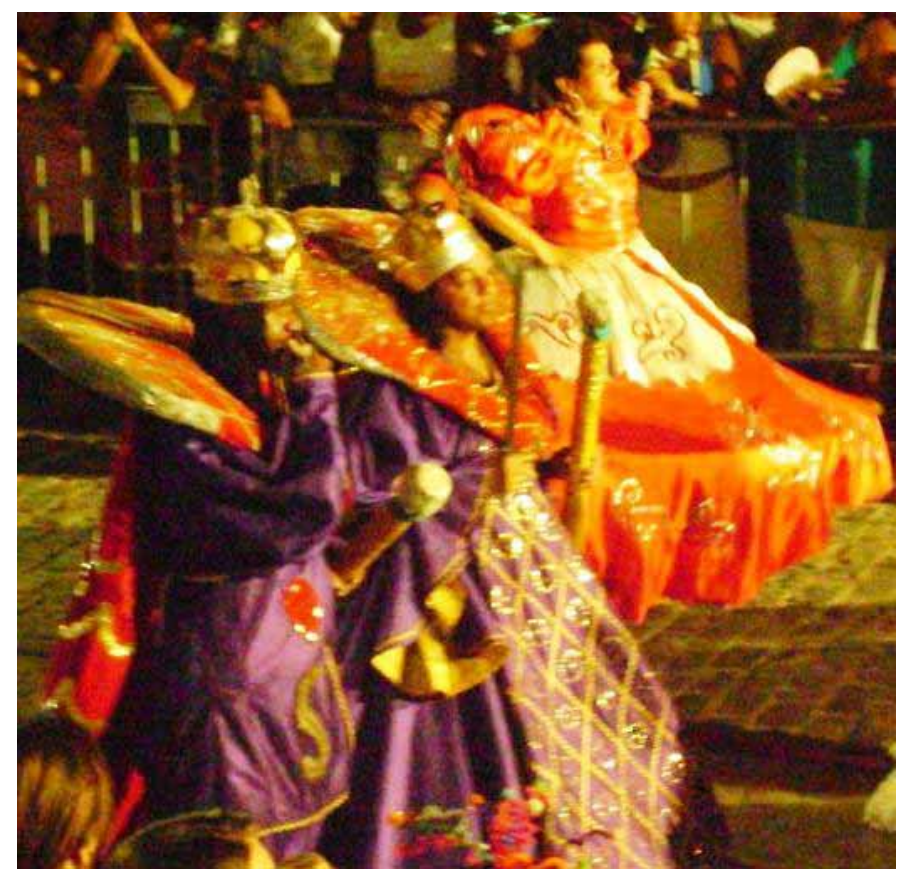

King and Queen / Photo: Jailma M Oliveira, 2010

Following the Court, throughout the whole procession or parade, comes a group of batuqueiros or percussionists - whose numbers, depending on the group, vary from 15 to 100 people. The group is led by a mestre - who acts as a maestro or conductor, guiding the male and female batuqueiros. The instruments used and present in all groups are alfaias, caixas (or snare drums) and a sort of metal bell, - gonguês. In addition, depending on the maracatu, in isolation or simultaneously, are the abê, the mineiro and the atabaques, which are drums utilized in Afro-Brazilian religious rituals. The following image gives an idea of what this whole set is like, emphasizing the alfaias.

Great attention is paid to percussion, especially to the mestre. He synthesizes the group and guarantees its harmony. He will be valued for his ability to produce new beats deriving from a mixture with other rhythms, such as funk and samba, for example. Invitations for presentations may include only the percussion (batuque), without the Court's presence. Participation in 
workshops adds to the mestre's reputation. However, when the Court travels, the Royal Couple, together with some nobles and Baianas are indispensable.

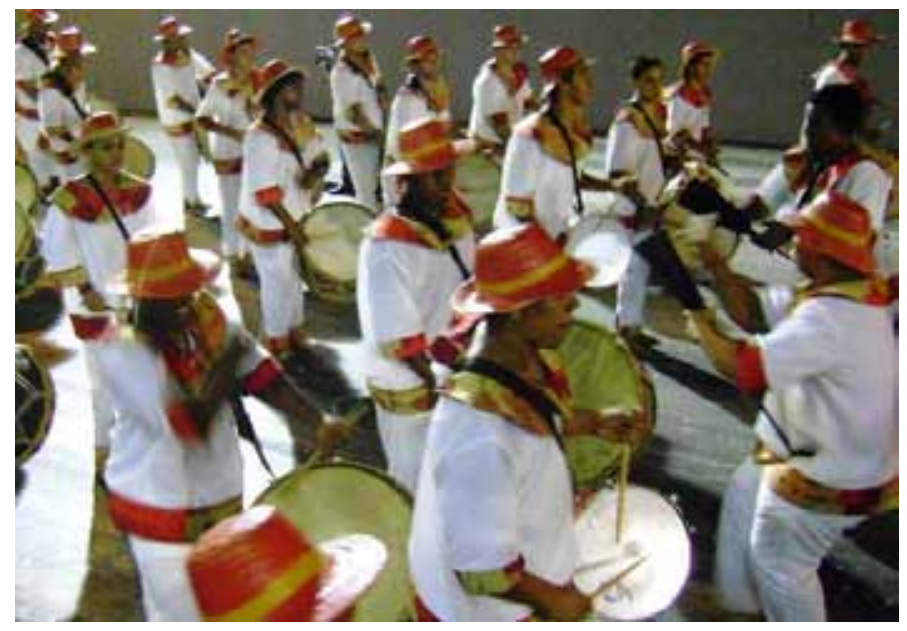

Batuqueiros / Photo: Jailma M. Oliveira, 2010

Inspired by documented data on the coronations of Congo Kings in the XVIII Century, (Souza, 2006), it is generally believed that Maracatus date from the period of slavery, which was abolished in Brazil in 1888. The composer Guerra-Peixe (1980), who carried out research on Maracatus during the 1950s, is still one of the most often cited authorities on the history of the Maracatus. He claimed that they originated to control revolts and black rebellions, serving as a form by which the blacks control themselves by naming a king. This is the reason why the Maracatus came to be called Nação (nation), as a way of invoking a collective idea with which the group identifies, offering a sentiment of belonging and obedience to authority. More recently, the term Nação has come to refer the groups' religious affiliation.

Lima (2008) challenges this explanation suggesting that the Maracatus were associated with the coronations of the Kings of Congo, and with other cultural forms. He also suggested that the contemporary Maracatu came into being during the Estado Novo period, which was characterized by the persecution of Afro-Brazilian religions, and by extension, Maracatus.

In spite of such disagreements, these histories provide plausible explanations for how Maracatu came into being, providing evidence of authenticity and antiquity of the groups as they compete for prestige and access to financial support that they need for their presentations, and which ultimately guarantees their survival. It also serves to establish adequate positions for 
men and women, particularly as far as playing instruments is concerned.

A consensus has grown that Maracatu is a playful dance restricted to black and poor people, for whom is marks racial and class identities. This characterization was accentuated in the 1980s, when the black movement reappeared in Brazil with the demise of the Military Regime that began in 1964 (Albuquerque, Fraga Filho 2006). Across the country, the Black Movement, especially, the Unified Black Movement (MNU) began to focus on popular cultural groups as vectors for the assertion of a positive racial identity, as the phrase "Black is Beautiful" did in the United States.

The presence of Maracatu in Recife's cultural scenario gained further momentum with the Mangue Beat movement (Esteves 2008). Starting in the 1990s, this movement, of which Chico Science and his band Nação Zumbi was the best known group, was inspired by popular rhythms mixed with international pop-rock rhythms. Mangue Beat became a symbol of regional identity and contributed to the visibility of other cultural manifestations. Together with Frevo, a popular manifestation regarded as a hallmark or Pernambuco's identity ${ }^{13}$, and Maracatu, the new rhythms of Mangue Beat, allowed Recife to claim a multicultural musical identity ${ }^{14}$.

In this context, Maracatu might have entered into competition with Frevo as the prime symbol of Pernambucano identity, especially since Maracatu occupies such a prominent position in the official opening of Carnival, where Frevo rhythms and dance are predominant. Carnival's opening takes place at the Marco Zero Square, beginning with the presentation of approximately 400 percussionists or batuqueiros, members of 14 Maracatu groups. This orchestra is directed by percussionist Naná Vasconcelos. This position highlighted Maracatu in an unexpected way in Recife's carnival. Before, its presence was restricted to the parades of the associations and to their presentations during the Night of The Silent Drums, both viewed by a specific public.

I consider that this was not what actually happened. As Maracatu gained this new position among Pernambuco's musical symbols, it did not lose its symbolic meaning as a manifestation of black and poor people. For the black population, Maracatu became stronger as a symbol of class and

13 Frevo (music and dance) has figured as the hallmark of Pernambuco's identity since the 1970s. I am unaware of the existence of any research/work dealing with this subject.

14 For a discussion on identity and music, see Lima (2009) and Pinho (2009). 
racial resistance to diverse forms of cultural persecution, permitting the reaffirmation of a sense of belonging as black and poor people (Lima 2008). Gender classifications, in contrast, are more neutral, since men and women have always been present in terms of relative equality in Maracatu since it first appeared.

This seems to have triggered an approximation of white and "rich" people (rich as a synonym for middle-class membership). This has brought change to the groups' internal organization, and gender relations themselves (Neves, Albernaz 2010). On the other hand, white and rich people's participation in percussion groups (Esteves, 2008) ) $^{15}$ has increased Maracatu's musical prestige, Maracatu then, is a powerful marker of Pernambucan identity and inspires new genres and musical styles, while paving the ground for the phonographic records of traditional toadas. Male and female batuqueiro percussionists are much admired, and an expressive number of people have set out to learn Maracatu for professional presentations or just as a hobby.

Bumba Meu Boi is defined as a dramatic dance ${ }^{16}$, of Portuguese origin, transformed in Brazil by African and indigenous influence. It involves the enactment of a fable through music and dance. The fable tells how a cowboy steals his boss's prize bull followed by the owner's desperate attempts to regain the animal ${ }^{17}$. The play is rarely enacted these days, but the characters remain and are parameters for the public's appreciation.

Its main characters are the amo or master, Father Francisco, Mother Catirina and the bull. The amo is the singer who commands the presentation, and during the enactment he is the owner of the bull and of the farm. His opponent is Father Francisco (Chico, Nego Chico), the character who steals the bull. Both characters are played by men. Catirina is the only female character

15 Groups based on Maracatu's music have been created to teach percussion or enable people to take part in carnival. Some of these groups even get paid for their presentations - within and outside the city. They do not have, however, a Court, nor are they affiliated to Afro-Brazilian religion. They are a source for strong polemics, as they compete with traditional Maracatus.

16 According to Mario de Andrade the dramatic dance is characterized by the enactment of a theatrical play, with relatively fixed characters, mixed with dances and music.

17 For a structural myth analysis, as well as their variants, as enacted in the Bumba Meu Boi ritual, see Cavalcanti (2006). See also Cavalcanti (2004) for an analysis of Mario de Andrade's contribution in the definition of dramatic dances. 
of the plot, Chico's wife, who spurs his husband into stealing the animal. Traditionally, Catirina's part was played by a man dressed as a woman. Nowadays, the role is either played by women or by travesties.
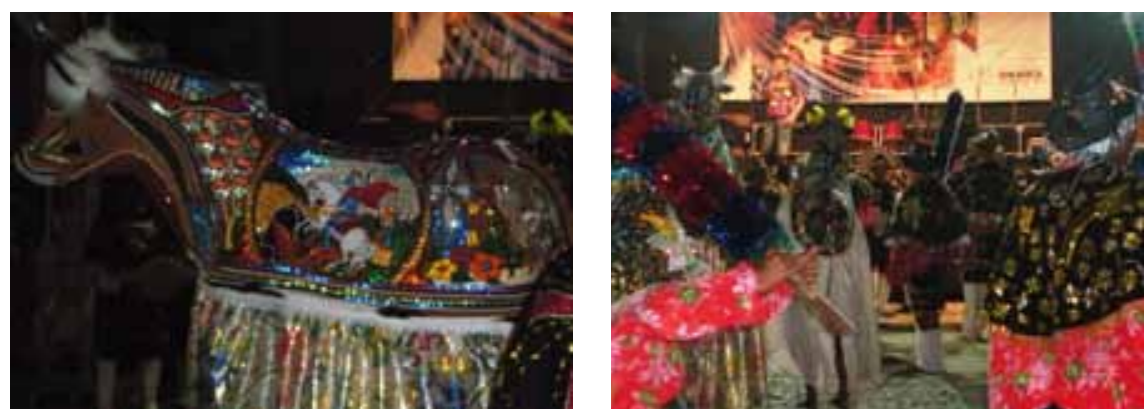

The bull Bull and cowboys / Photo: Patrícia G. B. de Lima, 2009

The bull is built on a wooden frame, covered with embroidered black velvet, animated by a man called Miolo (literally, the center, or the brain). Throughout the whole enactment, the bull is surrounded by cowboys whose dancing accompanies the animal, to give the impression that it is being taken care of, tamed and trained.

Completing the troupe are collective characters called Brincantes de Cordão, (Team of Revellers), who are asked to fetch the bull that went astray during the presentation. Their choreography varies from one Bumba Meu Boi group (sotaque, lit. accent) to another. They are Caboclos de Fita/ Rajados (Ribbon/Brindled Caboclos), and Indians, may be played by men and/or women.
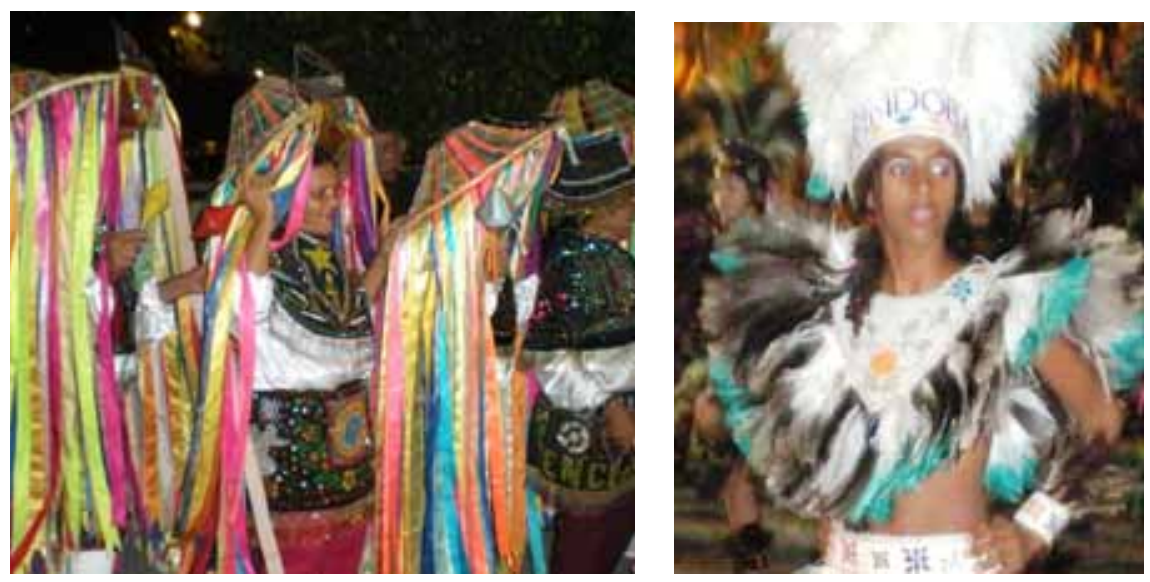

Brindled Indians / Photo: Patrícia G. B. de Lima, 2009 
These characters are present in all groups. However, there is a variation in the costumes worn, especially by the team of revellers. This is one of the points of reference for the classification of the Bumba Meu Bois into different "accents", which also include the rhythms, the instruments, the region of origin and, in some cases, the presence of additional characters. The accents are named after the instruments or the region of origin in the state of Maranhão. The principal and best known accents, or sotaques, are:

1) "Sotaque de Matraca" or wooden noisemaker accent [or Ilha (island accent)]: It comes from the island of São Luís. Its main percussion instrument is the matraca (wooden noisemaker), played by the group and by the public. Other instruments are large tambourines and jaguar drums (similar to a cuíca). The master or amo holds a cowbell to show the way to the instruments. These instruments are predominantly played by men. In the matracas the presence of both sexes seems to be equal.

2) "Sotaque de Zabumba" or bass drum accent [or Guimarães accent]: It comes from the city of Guimarães. Its main percussion instrument is the bass drum (held by wooden forks), followed by a little tambourine. The 15 to 20 musicians, who play behind the performers, are predominantly male. In the team of revellers, rattles are held by both men and women.

3) "Sotaque de Pindaré" or Pindaré accent [or Baixada accent]: This group comes from the Baixada Maranhese region. They use the same musical instruments as the Boi de Matraca do, although they are smaller in size, and there is a preponderance of men among the performers. In the brindled brincante team, men and women play small wooden noisemakers

4) "Sotaque de Orquestra" or Orchestra Accent: They come from the city of Rosário and Arixá (in the region of Munim). They are distinguished by the incorporation of wind and string instruments in addition to drums and rattles. There are ten to twenty musicians, mostly men. Brindled revellers and cowboys (men and women) hold rattles.

From the second half of the XIX Century on, Maranhão built its national fame on its literary production. The capital, São Luís, came to be known as the Brazilian Athens. (Atenas Brasileira). From the 1970s onwards, however, popular culture, especially the Bumba meu Boi, has became the principal symbol of distinction (Albernaz, 2004). Whereas in the past the Bumba Meu Boi was perceived as belonging to the poor and the blacks, it is now valued by middle-class segments of the population, a symbol of Maranhão without 
distinction of race or class. As such, the Bumba Meu Boi is the locus of narrative production, but it also mediates the experience of regional identity, through which different levels of belonging (the district, the city, the state, the Nation) are articulated. The increased celebration of the Bumba Meu Boi has led to an increase in public funding and also to the presence of women in influential positions.

If compared to Pernambuco, Bumba Meu Boi resembles frevo as a symbol of regional identity, while the Maracatu is a regional symbol that maintains the distinction of race and class. However, the "accents" of Bumba Boi are classified by race, class and also gender. Matraca is classified as the Bumba Meu Boi of the poor and the rich, of the racially mixed; Zabumba is composed of poor and black people, both symbolically espousing masculine values; Pindaré is a group of blacks and of the poor, but neutral in terms of gender; Orquestra is the Bumba of the rich and the whites and expresses femininity.

As in Pernambuco, where the increase in the importance of the Maracatu led to the approximation of middle-class people, so in Maranhão members of the middle class have formed cultural groups drawing personal and musical styles from various Bumba Meu Boi “accents”. Unlike Pernambuco these are institutionalized groups, referred to as parafolkloric or alternatives. They dance in the arraiais and are paid for their performances in the same way as the traditional groups which inspire them (Albernaz 2009). As far as we know, there was no movement like the Mangue Beat in the state of Maranhão. Rather, toadas were recorded by musicians who call their music MPM (Maranhão Popular Music in imitation of MPB - Brazilian Popular Music). Each year the state government provides subsidies for the recording of CDs for most Bumba Meu Boi groups, in a more systematic and recurrent way than happens in Pernambuco. This is possible because the Bumbas renew their toadas every year, as a way of seeking recognition and fame.

In both Maracatu and Bumba Meu Boi music is as, or more, important than other aspects of the performance. In Maracatu, the batuque or percussion gains increasing importance at the opening of carnival, to the detriment of the queens, kings, Damas do Paço, and the Mothers and Fathers of Saints of the Terreiros of the Afro religions to which the Maracatu is affiliated. Nowadays, the sound is better known by Recife's people than the history of the court with its kings and queens. 
In Bumba Meu Bois the amos, or masters, have the important role of overseeing the musical performance of the different accents under their responsibility. The CDs recorded by the groups are listened to at home and in automobiles. During the month of June the toadas are heard everywhere in the city and are learned by heart

The importance of music for the popularity of these festivities seems undeniable. These days, those who sing and play instruments gain higher status than those who only dance. This is because the dancers are not essential to the performance. And yet in some cases they may outshine the instrument players ${ }^{18}$. However, on the whole, the place of music seems to be more relevant, especially because it can still be heard when the presentations are over. In this context, women musicians have become more important.

\section{Gender and musical performance in Maracatus and Bumba Bois}

Academic and more popular writings on Bumba Meu Boi and Maracatu do not record the presence of women (Albernaz 2008). Lima (2008) is one of the few authors, who mentions the role of women in the Maracatu. As for as Bumba Meu Boi is concerned, Carvalho (1996) and Marques (1999) have given some attention to the issue, observing that women started playing a significant role in the Bumba Bois in the 1980 s $^{19}$.

During my fieldwork, I perceived certain reservations about the presence of women, who, it was claimed, had only recently entered the Maracatu. There is much debate over which instruments and what kind of singing they are allowed to take up. There are two recurrent positions: that it is not known when women started playing and singing and that they can play all instruments. Others are opposed to women having access to certain instruments and occupying certain positions.

In historical accounts of Maracatu, it is not clear whether women played instruments of percussion. (Neves, Albernaz 2010). Old recordings reveal the presence of women in the loas choir, in which they participate to this

18 The Orquestra Bumba Meu boi's female Indians are an example. The shape of their bodies are a magnet to attract public attention. But music still remains a central thing for the public's appreciation.

19 For restriction of space, I will not discuss women's presence/absence in the different positions they can occupy in the two groups. In another publication I deal with that issue (Albernaz 2008), especially for the Bumba Meu Boi. 
day. High tune singing is characteristic of their performances. In a study on afoxês, Souza (2010) mentions the prohibition of women playing leathercovered instruments for religious reasons. This explanation is present in the Maracatu.

The most common reason given for the prohibition of women playing drums is their "open body" ${ }^{20}$, with particular emphasis on the menstrual period. They could not mediate relations between the living and the dead by playing the drums because this requires "closed bodies" that are free from impurity. These are the reasons given by the master of the Maracatu Estrela Brilhante for not allowing women into the batuque. As a way of maintaining some coherence with religious precepts, the groups which do allow women to participate prohibit them from playing when they are menstruating, especially during the carnival period. Maracatu Porto Rico, in turn, allows women to play the more secular alfaia drum, but not the atabaque drum, which is used in religious rituals to communicate with the dead. As far as we could see, the atabaque drum is not present in other Maracatus.

Interestingly enough members of the Maracatu Leão Coroado - generally viewed as the oldest and most traditional Maracatu in Pernambuco and famous for the rigour of its Master, Luiz de França - remember that in the 1970 and 1980 s, a woman, Rosinete, taught the percussionists of this group. She did not, however, take part in the presentations. Apparently, women could be the bearers and transmitters of knowledge, but they could not demonstrate their knowledge and talent in public. This is an artful way of maintaining the fiction of masculine control of musical knowledge.

Most people agree that women joined the batuque mainly in the 199os, generally playing the alfaia Drums. There are two explanations for that, which I regard as complementary ${ }^{21}$.

First, women's access to batuque is accredited to the approximation of

20 This expression is recurrent in Brazil, and means to attract bad omens, especially as for susceptible to the evil eye. Men and women alike can have an open body

21 The sources for the following statements were interviews with masters: Ivaldo (Cambinda Estrela), Chacon (Porto Rico), Afonso (Leão Coroado) and with the clerk for cultural affairs and Maracatu, Junior. In an informal conversation with Bete de Oxum, whose personal life trajectory includes the presidency of an Afoxé, the creation of a percussion group based on Maracatu and currently leader of the point of Culture Coco de Umbigada (Olinda - Pernambuco). When we went over those issues she drew my attention to the relationship between percussion groups and women joining batuque in Maracatu. 
the Black Movement to Maracatu. Women of the Unified Black Movement included the feminist theme of gender as part of the debate over racism. In the early 1980s, Marta Rosa persuaded the leader of Maracatu Leão Coroado, Luís de França, to let her play. According to one account, it involved prolonged negotiations, during which Marta Rosa had to prove her expertise, strength and physical resistance to carry an alfaia ${ }^{22}$.

The second explanation goes that women started playing in percussion groups formed in the 199os, which, from the beginning, were made up of members of both sexes. Later on, they founded Maracatus with an exclusive female membership. Then, traditional Maracatus, under pressure from middle-class women, allowed them to participate. This was confirmed in the course of our observation, especially when we observed that there was a larger number of white middle-class women playing alfaia drums than women from the original Maracatu community.

Although not really explicit, the underlying meaning of the incorporation of women into the batuques represents a conquest, derived from the ideal of equal rights for men and women. For Marta Rosa, it was a conquest for black women with feminist inspiration. On the other hand, it was also a conquest for middle-class women derived due to a significant change in bourgeois family values over the past three decades, without necessarily recognizing feminism (Albernaz, 1996). In this last case, the feeling of belonging to a class seems to be more important than the modifications in gender relations. Middle-class people in Maracatu are viewed by the community members as being entitled to more rights than they themselves are, as evidenced by the treatment dispensed to them by masters and leaders. Having middle-class members in Maracatus strengthens the groups' fame, tradition and prestige ${ }^{23}$.

During the 199os the increase in the number of Maracatus brought about organizational changes that led to conflicts of opinion over which Maracatus kept or lost their traditional status. One cause of this polemic is the introduction of the instrument Abê, a calabash filled with seeds and covered with beads. For some, this instrument is characteristic of afoxé, and is not adequate for Maracatu. For those who hold this view, the ganzá

\footnotetext{
22 Marta Rosa has an emblematic participation in afoxé as well (Souza 2010).

23 Esteves (2008) presents batuqueiros' complaints who feel they are left out as they have to "give up their places" to the benefit of middle-class persons who pay to take part in the group.
} 
or mineiro ${ }^{24}$ are more suitable and produce similar sounds. Both instruments are played by shaking.
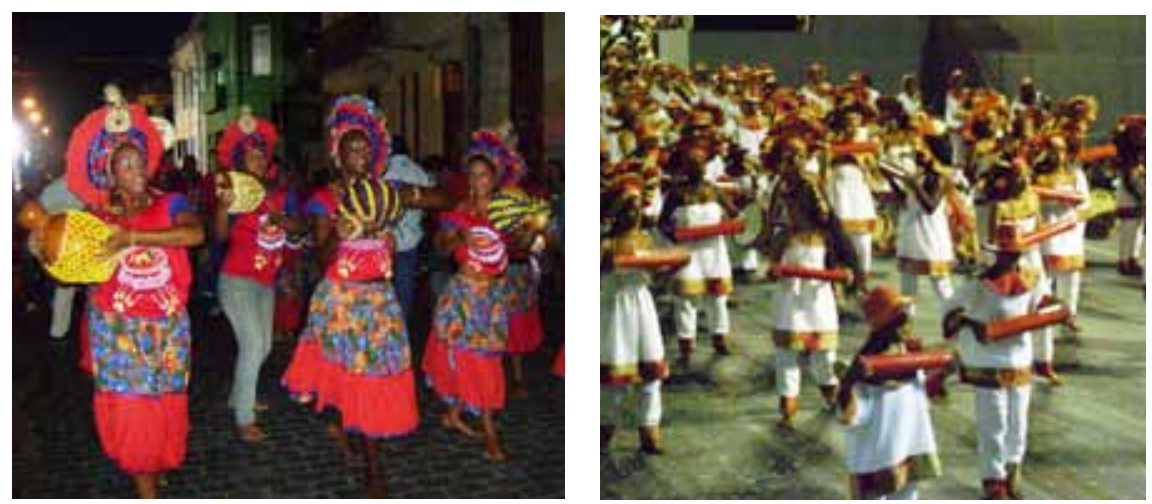

The abê The mineiro / Photos: Jailma M Oliveira, 2010

The ganzá is played by many women, children and young (see image above). The abê is the only instrument mentioned as one that is played exclusively by women. The reasons presented for that are different, but they all spring from notions of femininity and are also related to the bodily performance of the players. The same happens with ganzá, but the choreographies which accompany the abê playing seem more evident in all of the groups observed.

Which dimensions of femininity are invoked? It is said that abê enhances women's beauty and charm. In my interpretation, I consider that these terms refer to sensuality, a term not made explicit by most people, maybe because it alludes to sexual practices, which they prefer to avoid. Another reason for abê being appropriate for women is its relation with the female Orisha Oshum, the divinity of "sweet" waters (creeks and rivers), an incarnation of beauty, love, fertility, gold and other wealth. Although this Orisha protects men and women indistinctively, she is strongly associated with sensuous femininity. .

Maracatu managers, men or women, mestres and queens, agree that the abê is more beautifully played by women. They also admit that the instrument embellishes the batuque, attracting viewers' attention during processions and the carnival parade. Positioned ahead of the alfaias, women with

24 The ganzá has many shapes. See the most widely used in Pernambuco's Maracatus at: http://www. tudomercado.com.br/tm/aviso/img_avisos/Submarino_21310512.jpg e http://4.bp.blogspot.com/_ zALCoHLVn_Q/Rgwc1Ip1oNI/AAAAAAAAADY/xK7ZoO-rch4/s20o/ganza.jpg. Captured in 10/10/2010. 
the abê lead the Maracatu, opening the passage for the rest of the group.

Although there are no age restrictions on abê players, the women players seem by their appearance to be in the flower of youth, between 15 and 23 years of age. The choreography, which involves the shaking of the hips followed by an up and down movement of the arms, gives the playing of the instrument a touch of lightness and smoothness, making it an apparently "easy" and "light" task. The contrast with the "masculine" alfaias is marked.

The women who enjoy the abê are predominantly from the Maracatu's communities of origin. I heard it said that there are disputes among them to be able to play since the number of players is limited by the size of the percussion groups and the number of alfaias. Women also rival one another over the quality of their dancing. Girls compete over the kinds of dance steps or passos they will perform and who will lead the group. Such disputes are tougher and more recurrent in larger groups.

Alfaias are Maracatu's instruments which attract more attention. They are the most numerous and constitute the hallmark of the rhythm. Moreover, they can be found in other popular culture groups across the state of Pernambuco and across the country. There are many debates over them. Black activists claim that they are African and therefore symbols of negritude (blackness). Lima (2008), however, contends that they are of European origin $^{25}$. To guarantee the quality of the sound produced by the group as well as its tradition, it was established that the verdadeira (genuine) alfaia should be made out of the trunk of a carnaúba tree (Copernicia prunifera), and never from chipboard (much lighter).

The size of the instruments may vary. I saw that this occurs to allow young children and elderly people to play the alfaias, according to their sizes and physical resistance. About two thirds of alfaia players are men and boys, and women players tend to play smaller and lighter instruments made of chipboard.

As for the drumming itself, there are the alfaias de marcação (for marking the beat) and the alfaias que fazem as viradas (that make the turns). These drum beats are difficult to execute so that only a few can do it adequately. The fact that it is thought difficult to play is evidenced by the solemnity that

25 In a personal communication, Jorge F. Branco pointed out this question. African drums tend to be grounded, used for inter-village communication. European drums were mobile, used in war maneuvers. 
marks the facial expression of most batuqueiros and batuqueiras. But the hallmark of the scenic presence is the way the alfaia is played. The people who play it move their bodies, but the impulse of the arms with the drumsticks to give more volume to the sound seems to be a distinctive characteristic. As the afaia is played, there is an impression of the necessity of physical strength, to which is added speed and dexterity in alternating the left and right arms. The alfaia is constantly referred to as masculine, a sign of virility. Men's performance further accentuates this characteristic when they establish dialogues between their instruments. They engage in competitions to see who is able to maintain a challenge between their drums for a longer period. The larger the alfaia, the greater the competition.

However masculine the alfaia may be, I have not observed female alfaia players being subject to prejudice or discrimination. All insist that there is no difference between men and women players. Nor do they allow anyone to doubt their capacity as percussionists. Nonetheless, during one of the interviews, it was reported that women were having difficulty to convince male members of the group to teach them how to "turn" (como virar), the hardest of the beatings. Despite that, female alfaia players repeat the same bodily movements as men, copy the way of carrying the instruments, and make the same facial expressions of strength and commitment.

While women from communities prefer the abê, and while the alfaias are favored by middle-class women, one might infer that two gender codes are in circulation. On the one hand, the code that demands a consistency between sex and gender: women should be feminine. On the other hand, another code breaks this correspondence. Playing alfaia is not dependent upon sex, but it should be played according to the code of masculinity. This code cannot be inverted, that is, men may not express femininity playing abê. What can be said with relative certainty is that a relationship is established between the feminine man and a homosexual orientation, whereas women expressing masculinity are not necessarily homosexual. In other words, the hierarchies between the two ways of being favor the masculine side, giving it more value, a value women yearn for in order to challenge gender inequality.

This does not prevent women from accentuating their femininity in other ways. During rehearsals some of them wear customized shirts, lowcut shirts and tank tops with a bustier underneath. During presentations, men and women wear different costumes. Head adornments enhance female 
characteristics, as does make-up, the wearing of earrings, necklaces, and bracelets, carefully combed hair kept short or left to sway in the wind.

I should mention other key differences between the way the abê and alfaia are played. As the abê is shaked, it looks like an extension of their body. The alfaia is played by striking the drumsticks and, though these are kept close to the player's body, they appear to be separated from it. The sticks are never hidden and everyone can see that they are being carried, conveying the idea that it takes strength to use them. These two forms of playing seem to be naturally adequate to each sex/gender: the alfaia emphasizes masculine physical strength; the abê conceals the effort needed to be played, thus it is more appropriate for women, considered to be naturally fragile. It goes without saying that playing abê requires effort, concentration, as well as coordination between dancing and playing - not an easy task.

The other instruments, snare drums or caixas ( 3 to 5 per group) and gonguês ( 2 to 3 per group), are not subject to such heated debates. It seems they are considered to be gender neutral, played by men and women indistinctively.

Finally, a heated debate has grown over the past years over whether women should be able to occupy the master's place. Many who agree that women can take part in any position in batuque, argue that they are not apt to be masters. This is a very relevant issue, as the master is regarded as a kind of synthesis of the batuque; the conductor, the creator of rhythm, responsible for keeping control over the entire team. This polemic hits the target right in the bull's eye - name and address are known: Joana, female master of Maracatu Encanto do Pina. Currently, she is the only one to play this role. This fact has been looked upon as positive by a minority; for the majority, suspicion prevails, covert or overt, as to her capacity to command the batuque. During an interview, she said that her group might be given a low score on their first parade, but she would never accept having a low score because of her performance as a master. If this should happen, she would give up.

The reasons behind the suspicion come in varied forms. Women, it is claimed, do not have the capacity to lead so big a group of men. Women cannot play as well as men do. Joana is an abê player and so she cannot play alfaias. Another reason is that she is married to Chacon - Master of Maracatu Porto Rico. Some insinuate it is part of the family's strategy to gain access to more resources. Others claim that her husband is the "eminence grise" of the batuque, suggesting that she owes her position not to her own merit, but to her marriage. 


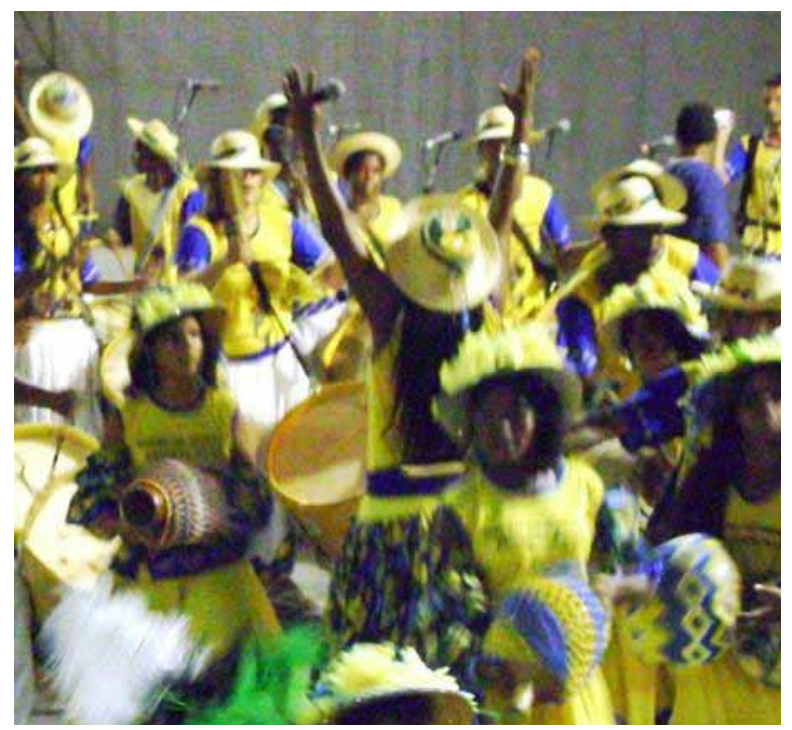

Joana, her arms raised, leads the batuque / Photo: Jailma M Oliveira, 2010

We have observed that women managed to gain access to percussion instruments when Maracatu gained value in Pernambuco`s music scene. This has been very positive in the sense that it has challenged gender-based power relations. The context is not free of conflict, however; rather it is markedly open to disputes over the meanings and the ways of classifying instruments and their players. The correspondence of sex and gender attaches, a more legitimate and comfortable place to women as abê players, more than in any other place. The most conflicting positions break a direct relation between sex and gender when women play alfaias or become masters. In the first case, women must prove their expertise, strength and express masculinity, challenging the notion that gender is an essence connected to biological sex. In the second case, the relationship between masculinity and power is challenged. It is said that Maracatu's "heart" is in the batuque. These kinds of challenges cause concern. Women are accepted as drummers, but changes in gender relations should not question male power.

Without a doubt, along Pernambuco's Maracatu history there have been significant examples of women leaders. Dona Santa (Queen of Maracatu Elefante) appears together with Luís de França (Master of Leão Coroado) with equal distinction and value, yet for different reasons. Dona Santa is hailed for her spiritual leadership, Luís de França for his musical abilities and his leadership in the batuque, in the oldest Maracatu in existence in Pernambuco. His role in the history of Recife's Afro-Brazilian religion is mentioned by only a 
few. One then might infer that women's power in Maracatu is associated with the sacred while for men, secular leadership seems more important; the capacity to negotiate with the authorities, to dominate the public sphere and to ensure the recognition of the Maracatu that ensures its continued reproduction.

Currently, this type of separation seems to persist. The queens Dona Olga (Maracatu Estrela Brilhante - Iguarassu) and Dona Elda (Porto Rico) are famous for their religious powers, but their Maracatus are led by their male masters, Gilmar and Chacon, respectively. This complementary relation between a spiritual and a secular power is evident during carnival's opening ceremony when the group's religious leadership is incarnated in the queens. The Night of the Silent Drums reproduces these meanings. Dona Marivalda (Maracatu Estrela Brilhante - Recife), is however something of an exception, as she takes up the presidency of the group. It seems that this position is determinant for the exercise of power regardless of the sex of whoever occupies it, but it does not invalidate the assumptions that sacred power is basically feminine, while temporal power is predominantly masculine and generally exercised by the master.

For this very reason, the abê becomes reinforced as the most adequate instrument for women. It is not central in the group, and, as a feminine object associated with a female Orisha, it extends the mediation with the sacred carried out by the queens. In the past, as now, it is surprising to see women playing alfaia and occupying the master's position - two activities traditionally belonging to the masculine realm and central in the batuque, closely related to financial and political powers.

Now it is time to analyze the case of Bumba Meu Boi. Members of Bumba meu Boi groups are called rapaziada (bunch of guys). According to the literature, women who participated were called mutuca ${ }^{26}$ (a kind of horsefly). The term is still used and is applied to women who work in the organization and the logistics of the presentations, serving water and snacks during the circulation of the bulls among the arraiais ${ }^{27}$. Just as in the case of Maracatu, the literature on Bumba Meu Boi is silent on the issues of women's participation

26 The name of the flies found in corals in Northeast Brazil. It has a derogatory meaning.

27 The circulation from one arraial to another may last all night until early morning. Managers are responsible for snacks and drinking, but the mutucas are in charge of the distribution 
as players of instruments. Instead, the main focus is laid upon the amo' ${ }^{28}$ performance. There are no historical records informing of female participation either as musicians or as composers of toadas.

The lyrics of the toadas' are very important in the competition between rival groups. The themes range from political facts to celebratory dates, sports events, facts pertaining to the group's everyday life, including the group's assertion of identity ${ }^{29}$, as in the example below.

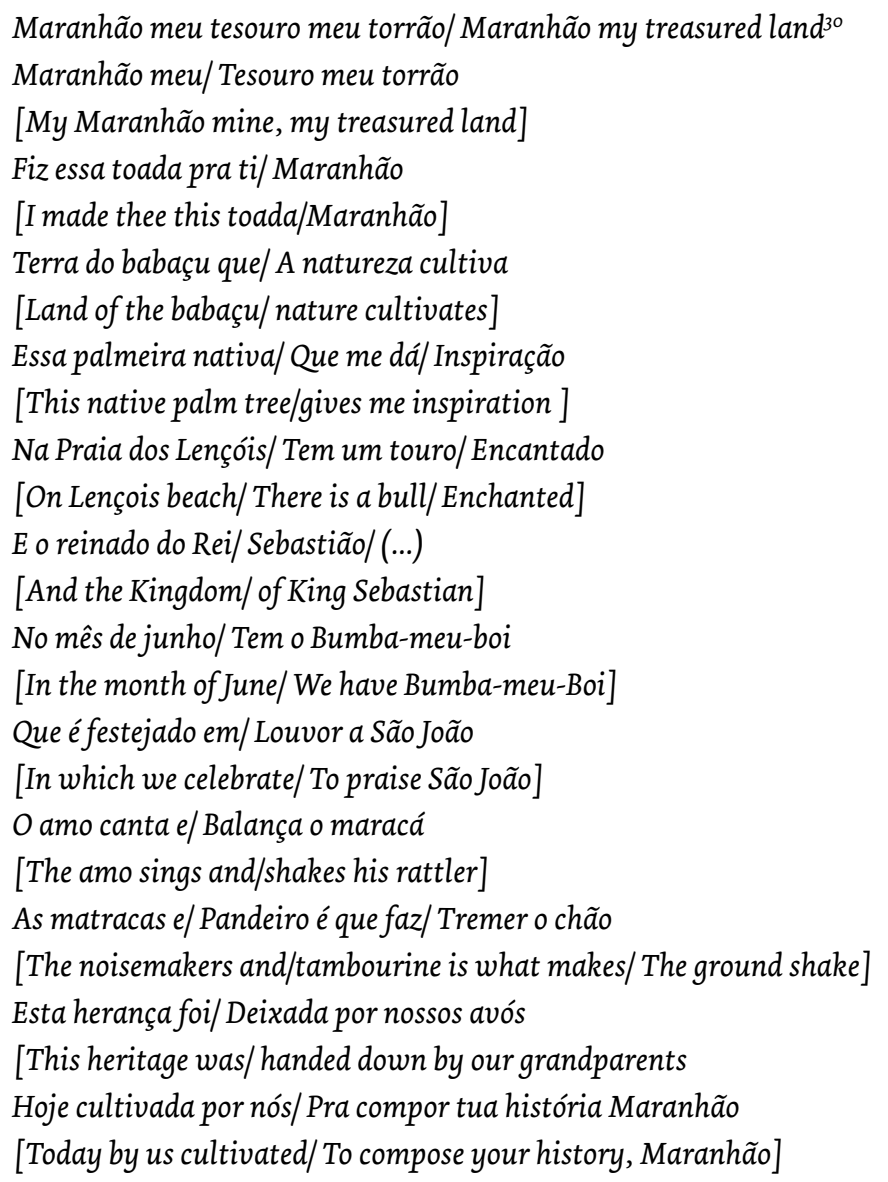

28 The amo may or may not be the group's president, in charge of the organization and the negotiation of presentations with institutions. Regardless, the amo is the authority during presentation.

29 For Vieira Filho (1977) the toadas would function as an "annual newspaper" for the groups, and that is where its importance for the group Lies.

30 Original toada, 1986, Singer Humberto. CD Luz de São João (200o) Bumba-meu-boi de Maracanã Band number 12. Translation is a free adaptation by the translator and revisors. 
Originally, the toadas were improvised by the amo who should therefore have poetic qualities. As Burke (1989) once pointed out, improvisation is more a desire than a reality. Popular poetry follows a pre-established formula, variation being related to themes. Improvisation is, in fact, learned, but always hailed as a special talent that few have. This meaning remains unaltered for Maranhão's people, despite the recordings of toadas which highlight the suppression of improvisation. The evaluation of the amo is still centered on his poetry. The theme each Bumba Meu Boi will bring, as well the quality of the toadas, is matters of great expectation. The outstanding toadas are repeated in the following years, as in the example above.

Local people's perception is that poetry-making is an innate gift. It is a quality of the spirit, which endows the person with the right to speak. Its content expresses the group's world view, conveys its history and underscores active resistance against injustice. Because of this quality, the amo gains public acknowledgement, that emanates to the rest of his group, while it reasserts his legitimacy as an amo and leader. This gift is connected to another one, the potency, tone and scope of his voice, which will enable him to exercise the command of the group. Thus, he expresses his authority through singing; authority reinforced by the age of the amo, usually in his fifties or older. Both qualities are inherent to men, and are not dependent upon training or learning. You either have them or do not. Women have neither the tone nor the scope to sing and conduct the group. They cannot make poetry either. These arguments are repeated today, and women are disqualified beforehand to occupy this position.

The amo has a second function in a group's musical performance that is related to the positioning of the musicians, to the team of revellers (or bincantes de cordão) and to the Bumba Meu Boi's characters. The presentations have three forms ${ }^{31}$. In the Matraca accent Bumba Boi, the dance takes place within a circle with the bull and the characters in the center - the musicians with large tambourines, rattlers and jaguar drums are outside the circle. Sometimes, the amo is in the center with the dancers; others times, among the musicians.

The Pindaré accent dance happens in a semi-circle formed by the musicians (in the center), the brindled, male and female Indians and, ahead of

31 As the Orquestra accent has a very particular form, I will deal with it separately. 
them, the bull and the characters. The brindled and female Indians move, forming a circle and returning to their original place. Musicians do not follow this movement. The amo stays at their side all the time and hardly ever goes up front or circulates around the team of revelers. It is as if he mediates between one group and the other.

The Zabumba accent has a similar arrangement, though it accentuates the presence of musicians, positioned behind the semi-circle. This happens on account of the bass drum's size - large, and at the same time held by wooden forks (see image below, on the background). The amo goes ahead of the group and, as in the Pindare accent, he circulates very little around the revellers.

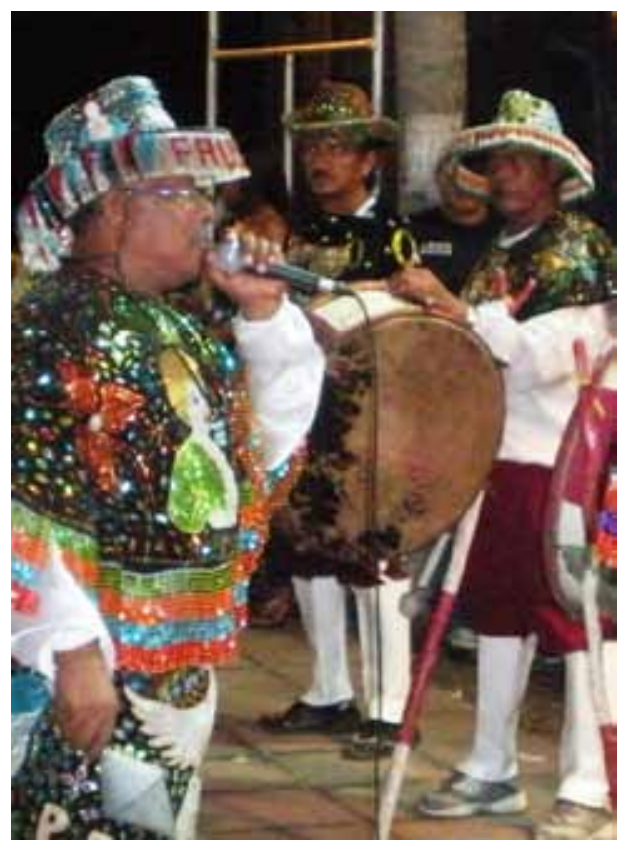

Amo of the zabumba accent 32 / Photo: Patrícia G. B. Lima, 2009

This proximity between dancers and musicians, one looking like the extension of the other, requires the dexterity of the amo to ensure the musical development. The development depends upon how the amo sings and when he invites the instruments to follow his opening "a capela". In order to signal his entrance, he raises his arm up high and shakes his maracá or rattler (the

32 Note the maracá in the amo's hand. It is raised to indicate the entrance of the musicians, who are in a waiting position, prepared to start the performance. All amos sing directly at the musicians, not at the public, watchful of their concentration and of the presentation's continuity. 
instrument in the amo's hand in the picture above). This gesture is repeated at each new toada, and is also done to entice the diversion of the group's members or increase the sound of the instruments. It also serves to prevent them from losing the rhythm. If it happens, it is said that the "bull crossed".

Another denomination for Bumba Meu Boi is batalhão (battalion). I believe this term is more associated to the music than to the dance. The peso do batalhão (weight of the battalion) is based on the synchrony of the instruments, conducted by the amo's voice and maracá. During presentations, I heard many people saying that the bull would "cross" (lose its rhythm) because the amo had started his singing in an inadequate form and had not shaken the maracá at the right time

The position of the amo in the beginning of the presentations is also important. The guarnice (the first toada) invites the group to get together and is the first voice of command. The contiguity between dancers and musicians gives the amos two possibilities: singing for the public or for the musicians. When they start singing with their backs to the public, they ensure the musicians' concentration. There are those who start facing the public, and then turn to the musicians, attracting the attention of both.

The amo is not alone in maintaining the musical development. Almost all of them have a helper who shares the responsibility of singing and coordinating the execution of the instruments. They correct the musicians, make sure amusement is maintained and the public enthralled. The helper can be someone the same age as the amo, or he can be a young man initiating his learning. It is simultaneously a process of knowledge transmission and a task shared by men of outstanding positions.

Special attention should be given to the Orquestra accent Bumba Meu Boi because there are some striking differences when compared to the other types of Bumba. The group of musicians and dancers are clearly separated. Wind and string instruments require amplification (use of loudspeakers), and musicians are placed on a platform (or stage, depending on the arraial's structure) above the dancing group, while an orchestra director conducts the music ${ }^{33}$. In this Bumba Meu Boi accent, the function of the helping singer is different. There are more people taking turns with the amo, each

33 The dance is in the form of a rectangle, with the bull at the center, flanked by rows of cowpokes and female Indians. 
having relatively the same value, but never obfuscating the amo. Despite the fact that this accent is classified as feminine, curiously, men remain prevalent among the musicians, at the same time that female singers seem to outnumber the men. This happens because in this accent the toadas are more lyrical, expressing themes such as nature, beauty and, love, not directly implying the notion of an authority who is the spokesman of the group, as happens in other accents.

In the Orchestra accent Bumba Meu Boi, the importance given to the musical performance is often linked to a greater importance of a well rehearsed and synchronized choreography -- when compared to the other types of Bumba. A female character stands out from group - the Indian, principally because of her youth and body shape. For that very reason, the focus on the amo is dislocated, allowing women to join in, singing in a more expressive way, at least apparently. It was in a Bumba Meu Boi of this accent that I found a woman President, who also was a self-assigned amo, on account of her administrative role.

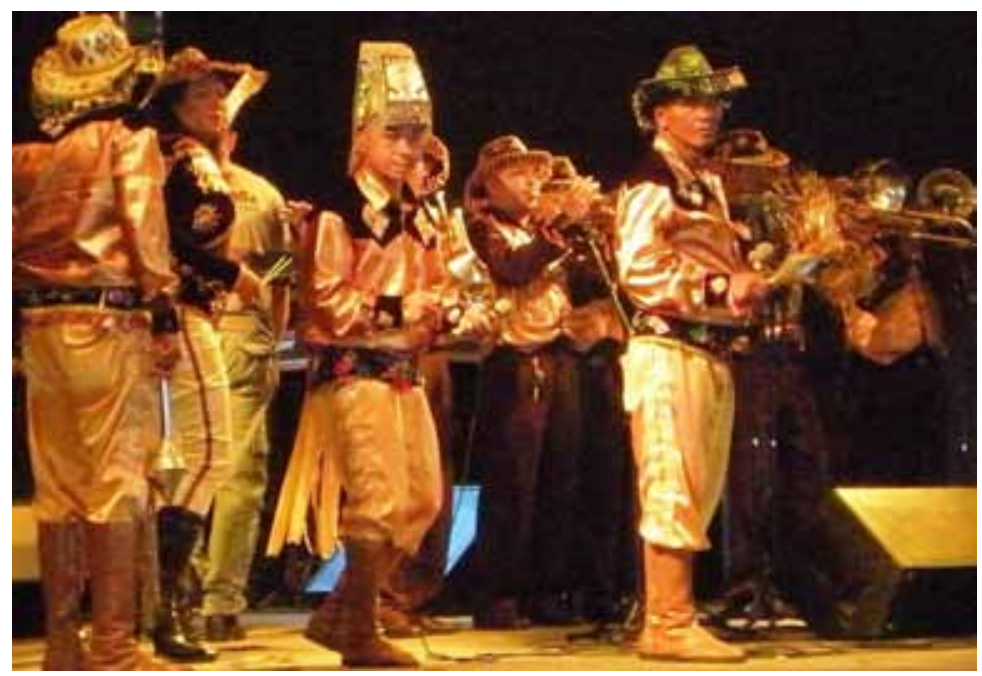

Orquestra accent musicians / Photo: Patrícia G. B. Lima, 2009

All the expectations concerning the amo converge to prevent women from occupying this position. Becoming a poet and singer depends on innate gifts, which you either have or do not have, regarded as inherent to men Women, therefore, cannot gain these qualities by training or by education. In addition, there are two other justifications which inhibit women's occupation of these positions: protection and moral control (Albernaz 
2008). Protection means sparing them from physical fatigue as well as from assuming responsibility for management activities. The control over sexuality is connected to morality. Women in a millieux surrounded by men are thought to be at constant risk of being wooed. If they accept being courted, and the pair is inadequate, they jeopardize their authority as managers. If they do not accept it, they put their own safety at risk. In both cases, men might engage in fights to protect them, and this could threaten the group's continuity.

These two justifications to discourage women from taking up the amo's position are extended to deprive women of their confidence to play instruments. Bumba Boi's instruments can be broadly classified into two types: those played by the group of musicians and those played by the team of revellers as they perform their choreography. In the first case, men are predominant. In the second, men and women can play indistinctively.

I consider the percussion instruments of the Matraca accent to be emblematic of this separation ${ }^{34}$. The arguments presented by people who are fans of, or take part in, this Bumba Boi are the same one can find in the other accents. The instruments of this Bumba Boi accent, in order of prevalence, are: noisemakers, large tambourines, (depending on the group's size, they vary from 10 to 70), jaguar tambourines (around 3, regardless of the group's size). The rattlers are used by the amo and his helpers to lead the development of the presentation.

The people I heard claimed that women had little expertise in playing large tambourines, lacking musical ability as well as the strength to carry them. These tambourines are not very heavy, but the position to hold them (it is played resting on the shoulder, near the ear, striking it with the hand opposite to the shoulder where the instrument is placed. See image below) is seen as tiring and demanding physical strength that women wouldn't have. The fact that the presentations last long would be another impediment. Since the peso do batalhão (battalion's weight or simply its synchrony) is dependent upon the development of this instrument, women could jeopardize the group's success.

34 I will not spend time on each accent individually due to the limits of space and in order to shorten the discussion. I point out that for the Orquestra accent, which has wind and string instruments, the arguments are not different. 


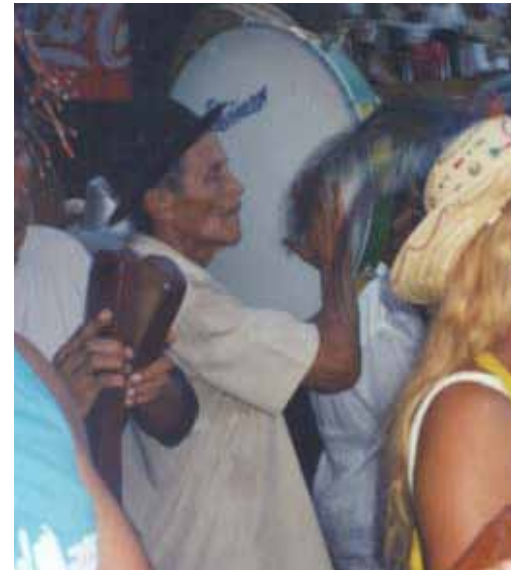

Pandeirão as it is played (behind) Photos: Lady Selma F. Albernaz, 2001.

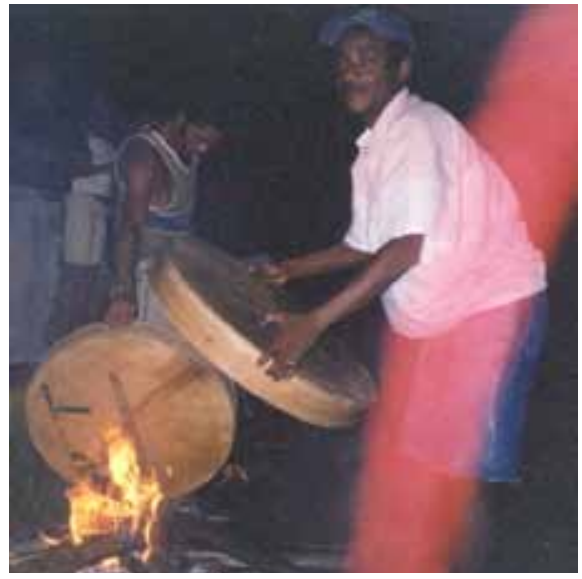

Pandeirão being tuned up

These are covert arguments, as happens in the Maracatu. Women are said to be able to play any instrument and to be welcome. Nonetheless, men are the majority playing the large tambourines in all Bumba Bois I saw. Women are hardly ever in this function. When they are playing, they seem to be more external to the group than internal to $i^{35}$.

As far as noisemakers are concerned, no one says women are not allowed to play them. Noisemakers generally are variable in size in accordance with the player's resistance. There are noisemakers whose length is superior to 1 meter (played by two people) and noisemakers as small as $20 \mathrm{~cm}$ (the most common). The way of playing varies from sophisticated to simple - in this case, as simple as clapping hands. But in both cases, it requires technique and rhythm. However, the most elaborate playing form, by clapping and rubbing simultaneously one piece of wood against the other, is considered the one that produces the finest sound quality and a parameter to evaluate the music. The amos and their helpers are always keeping a watchful eye on noisemaking people because, in general, it is from this group that sound overlapping (losing the rhythm) comes as music develops; the larger the group, the greater the risk. Because of the varied ways of playing and the

35 In the Matraca accent people from outside the groups are accepted to play large tambourines, but it is clear who belongs to the group and follow it from one arraial to the other. It is to them that the amo and his helpers direct their attention to maintain the development of the music. The same happens with the matraca players. In the Pindaré and Zabumba accents, this seems not to happen, as far as I could see. In the Zabumba accent, sometimes, there were people from outside playing the tambourine. In general, young middle-class people. These issues deserve further analysis. 
need to for the size of the instrument to be adequate for personal capacity of players, the arguments of strength and physical resistance, as well as expertise, are not invoked to interdict women. However, men are predominant among the players within the group.

The majority of the people who join the Bumba Boi to play, do it with a matraca, including those who play while seated to watch the presentation. In this case, it is not possible to establish if men or women prevail. What is known as a fact is that, until very recently, women following the Bumba Bois with their noisemakers were subject to suspicion, if unaccompanied by males. The main reason for the suspicion, in this case, falls upon the morality of an unaccompanied woman in a Bumba Meu Boi group would certainly be considered to be in search of a man to court or in search of a chance encounter. Canjão (2001) examines this issue and, based on DaMatta's theoretical framework, believes that the Bumba Boi reinforces the separation between the woman of the house and the woman of the street.

Still, it is worth pointing out that the smaller the noisemaking instruments, the more they seem to be an extension of the body, a way of enhancing the sound of hand clapping, as if only the hands were used to accompany the key instruments. The movements of the body follow the rhythms of the dance, while they accentuate the concentration for the appreciation of the poetry being sung. Thus, it similar to the performance of the abê and the ganzá in Maracatu, because it doesn't show a clear separation between the body and instrument. Even if this expression seems to relate to masculine values when one plays the matraca, this symbology is less emphasized.

This interpretation seems more evident when we extend the view towards other instruments present in other accents and which have similar functions, but which are played by the dancers, like the small rattlers present in the Orquestra and Zabumba accents and the noisemakers in the Pindaré accent. They increase the sound of the principal instruments and act like a choir to them. It is as if they accentuated the stamping of the feet, that characterizes the dancing of these accents. It doesn't matter whether men or women are playing. What is important is that they complete the dance and the choreography by occupying their hands. The actions of protection and control aiming to interdict women to gain access to the instruments then become unnecessary. 


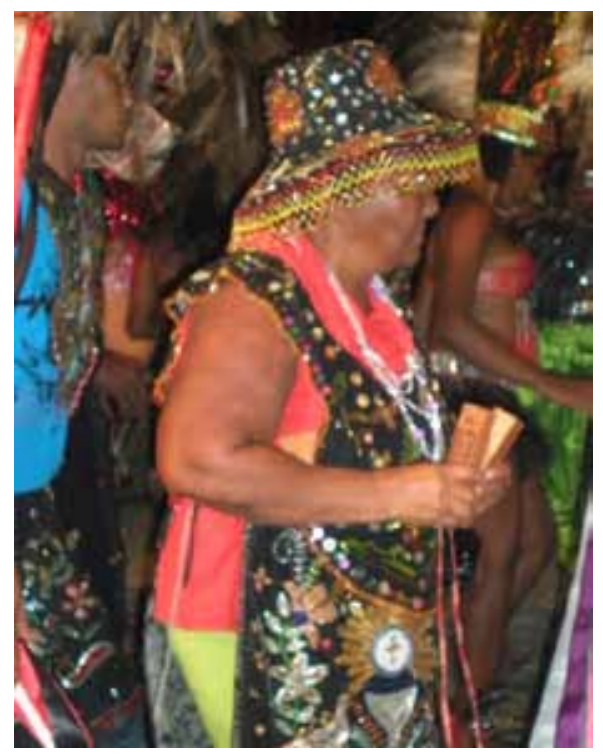

Rajado (Pindaré accent) with a small rattle / Photo: Patrícia G B de Lima, 2009.

At the same time, women conquered many positions within Bumba Meu Boi. They can play among the team of revellers, acting as any of the characters, something they could not do previously. They have taken up leadership positions in Bumba Meu Bois, regardless of the accent. There are many examples of women presiding these organizations. However, they do not obfuscate the amo, nor his synthesis for enjoyment nor his music; and many of them value the amo's work as a support for the success of the group, for which he is a synthesis. But that raises the question of why in the musical performance of the most relevant instruments women remain a minority or why they are a minority as Bumba Boi's amos, little known or unknown in this function. I consider that what comes into play here is the moral control and protection that prevent responsibility. But this is a clearly evident idea: as a mutuca (horsefly) or as a president, responsibility remains. It seems that by restricting women's access to musical performances, men interdict their prestige, and this helps to maintain the encompassing value of masculine over the feminine. Once again, as happened in the Maracatu, culture's deepest dimensions informing subjectivity remain the foci of resistance to gender transformations.

In order to save the reader from a melancholic ending, it is important to highlight some achievements which have transformed the Bumba Boi from a predominantly male event into a more flexible one in which women may 
join. In Maracatu, women have held firmly to the alfaias, mixing new symbols and meanings of what is feminine to what is masculine, which might bring about new changes to alter subjectivities molded in inequality.

\section{Bibliographical References}

ALBERNAZ, Lady Selma Ferreira. 1996. Feminismo, porém até certo ponto... Dissertação de Mestrado em Antropologia, UFPE - Recife.

ALbERNAZ, Lady Selma Ferreira. 2004. O "urrou” do boi em Atenas: instituições, experiências culturais e identidade no Maranhão. Tese de Doutorado em Ciências Sociais, UNICAMP - Campinas.

ALBERNAZ, Lady Selma Ferreira. 2008. "Mulheres e cultura popular: gênero, raça, classe e geração no bumba meu boi do Maranhão". In: Anais da 26a․ Reunião Brasileira de Antropologia, Porto Seguro (cd-rom).

ALBERNAZ, Lady Selma Ferreira. 2009 [no prelo] "Estéticas e disputas em torno do Bumba-meu-boi (São Luís, Maranhão)”. Revista Anthropológicas.

ALBUQUERQUE, Wlamyra R. de; FRAGA FILHO, Walter. 2006. Uma história do negro no Brasil. Salvador: Centro de Estudos Afro-Orientais; Brasília: Fundação Cultural Palmares.

BURKE, Peter. 1989. Cultura popular na Idade Moderna. Europa, 1500-180o. São Paulo: Companhia das Letras.

CANJÃo, Isanda Maria Falcão. 2001. Bumba-meu-boi, o rito pede "passagem" em São Luís do Maranhão. Dissertação de Mestrado em Antropologia Social, UFRGS - Porto Alegre.

CARVAlho, Maria Michol Pinho de. 1995. Matracas que desafiam o tempo: é o Bumba-boi do Maranhão, um estudo de tradição/modernidade na cultura popular. São Luís: Sem editora.

CAVALCANTI, Maria Laura Viveiros de Castro. 2004. "Cultura popular e sensibilidade romântica: as danças dramáticas de Mário de Andrade”. Revista Brasileira de Ciências Sociais, 19(54): 57-78.

CAVAlCANTI, Maria Laura Viveiros de Castro.2006. “Tema e variantes do mito: sobre a morte e a ressurreição do boi”. Mana. Estudos de Antropologia Social, 12(1): 69-104.

CRUZ, Danielle Maia. 2008. Sentidos e significados da negritude no Maracatu Nação Iracema. Dissertação de Mestrado em Sociologia, Universidade Federal do Ceará - Fortaleza. 
ESTEVES, Leonardo Leal. 2008. "Viradas" e "marcações": a participação de pessoas de classe média nos grupos de maracatu de baque-virado do RecifePE. Dissertação de Mestrado em Antropologia, Universidade Federal de Pernambuco - Recife.

GUERRA PEIXE. 1955. Maracatus do Recife. Rio de Janeiro: Ricordi.

LIMA, Ari. 2009 [no prelo]. "De 'sobrevivências' culturais africanas a uma cultura negro-africana e popular”. Estudos Afro-Asiáticos.

LIMA, Ivaldo M. F. 2008. Maracatus e maracatuzeiros. Recife: Bagaço.

MARQUES, Francisca Ester de Sá. 1999. Mídia e experiência estética na cultura popular: o caso do bumba-meu-boi. São Luís: Imprensa Universitária.

NEVES, Ighara Oliveira; ALBERNAZ, Lady Selma Ferreira. 2010. Concepções sobre corporeidade e fertilidade femininas entre brincantes de bumba-meu-boi maranhense e de maracatu pernambucano. Relatório de Iniciação científica (Ciências Sociais) - Universidade Federal de Pernambuco, Conselho Nacional de Desenvolvimento Científico e Tecnológico.

PINHO, Osmundo. 2009 [no prelo]. "Resistência e contradição: o carnaval afrodescendente como carnaval popular.” Estudos Afro-Asiáticos.

SILVA, Carlos Benedito Rodrigues da. 2000. Ritmos da identidade: mestiçagens e sincretismo na cultura do Maranhão. Tese de Doutorado em Ciências Sociais, PUC - São Paulo.

SOUZA, Ester Monteiro de. 2010. Ekodidé: poder feminino e relações de gênero no contexto dos afoxés de culto nagô no Recife. Dissertação de Mestrado em Antropologia, Universidade Federal de Pernambuco - Recife.

SouzA, Marina de Mello e. 2006. Reis negros no Brasil escravista. História da Festa de Coroação de Rei Congo. Belo Horizonte: Editora UFMG. VIEIRA FILHO, Domingos. 1977. Folclore brasileiro. Maranhão/ Rio de Janeiro: MEC/DAC/FUNARTE/CBDF.

\section{About the author}

Lady Selma Ferreira Albernaz: Doctor in Social Sciences (UNICAMP), Anthropology Professor at the Department of Anthropology and Museology (UFPE), Researcher at the Center of Family, Gender and Sexuality (FAGES) in the areas of anthropology, gender/feminism and popular culture, themes of the courses offered in the undergraduate and graduate programs in anthropology. She is currently conducting post-doctoral study at ISCTE 
- Instituto Universitário de Lisboa, in collaboration with Prof. Jorge Freitas Branco. She has academic publications in books and journals about the above mentioned themes.

E-mail: 1s.albernaz@uol.com.br.

CV-Lattes: http://buscatextual.cnpq.br/buscatextual/visualizacv. jsp?id=K4723756E6.

Address for regular mail:

Rua Francisco Correia de Araújo, 315 ap 201 - Várzea

50.740-430 Recife-PE

Received 12 October, 2010, approved 12 May, 2010 